\title{
The implementation of favorite picture media for increasing speaking skill in descriptive text
}

\author{
Masning Suaidah \\ SMAN 1 Kawedanan Magetan, Indonesia
}

\begin{tabular}{lll} 
Article Info & & \\
\hline Article history: & & \\
Received January 12, & 2019 \\
Revised March 20, & 2019 \\
Accepted June 16, 2019 & \\
\hline
\end{tabular}

Keywords:

Favorite Picture Media Speaking Skill

\begin{abstract}
The aim of the study is to increase speaking skill in descriptive text by the using of favorite picture media. It is found that there are many students have less interest and activity during English lesson, especially in speaking material. It is because the students get bored during the lesson and the teacher teaches monotonously.. The research design is class action research. Population of this study are 34 students of X MIPA 6 grade SMAN 1 Kawedanan Magetan in first semester, academic year 2017/2018. This research is conducted in two cycles, and each cycle consists of: (1) plan; (2) action implementation; (3) observation; (4) reflection and evaluation. The result of this research shows that in the second cycle, there are $88 \%$ or 30 students have good activity during learning process and students' learning result in average have gained 80 grade, which is maximum passing criteria (KKM) in English lesson is 75 . In conclusion, the application of favorite picture media is able to increase speaking skill in the form of descriptive text.
\end{abstract}

Copyright $(0) 2019$ Department of English Teaching. All rights reserved.

Corresponding Author:

Masning Suaidah

SMAN 1 Kawedanan Magetan

Jalan Raya Genengan Gorang Gareng, Magetan, Jawa Timur, Indonesia

Email: masningsuaida@gmail.com

\section{INTRODUCTION}

Teaching is an effort to make students learning, which is an attempt to make change in student's behavior. Behavior transformation happens because of interaction between student and environment. The transformation depends on two factors (Gagne in Enok, 1987). Internal factor is the detention of student's readiness in accepting behavior transformation. If student has enough basic knowledge or skill he will be able to increase his knowledge or skill by the assistance of environment. External factor is student's environment which can stimulate, support and accelerate learning process.

Therefore, teaching means organize student's environment to build interaction between student and his environment so that learning process can be achieved. Many teachers implement Contextual Teaching Learning (CTL) approach in English class. CTL approach assists teacher in connecting teaching material with student's real world situation and encourages relation between students' knowledge with the implementation in their life (Depdiknas, 2002: 1).

Based on daily test of first semester, basic competence 3.4 mentions that differentiating social function, text structure and linguistic component of some spoken and written descriptive text by giving and asking information related with famous tourism place and historical building, short and simple, in accordance with the user's context, has not shown maximum result. By minimum completeness criteria 75, only 17 students from 34 students have reach grade up from minimum completeness criteria. Thus, this study implement favorite picture media for increasing speaking skill in descriptive text. 


\section{METHOD}

\section{A. Research Design}

The design of the research was a Class Action Research. The approach of this research was a qualitative descriptive approach that intended to understand the phenomenon of what was experienced by the research subjects such as behavior, perceptions, motivations, actions and others.

\section{B. Participants}

This research was conducted on students of $10^{\text {th }}$ MIPA 6 during first semester in SMAN 1 Kawedanan, Magetan Regency in academic year 2017/2018, with the number of students were 34 students that consists of 20 male and 14 female.

\section{Procedure}

This research was carried out in two cycles, where each cycle consisted of several steps, namely (1) plan; (2) implementation actions; (3) observation and data collection; (4) reflection and evaluation.

\section{Instrument}

The instrument used was to measure the success of actions from two sides (the process side and the side of things observed). The instruments used were tests and observations. In this case the author used teacher and student observation sheets and written learning outcomes tests.

\section{E. Data Collection Technic}

Data collection was done in two ways. First, measurement of learning results tests was through pretest and post-test and learning results test instruments. Data on learning activities were through observation and interviews. Observation sheets were the data about attitudes (motivation, attitudes, etc.) through questionnaires.

\section{F. Data Analysis Technic}

Data analysis in this research used qualitative data analysis, namely the analysis of data obtained in the form of sentences and activities of students and teachers. The analytical model used by (Milles and Huberman, 2012) was the flow model, which includes three things (a) data reduction, (b) data presentation, and (c) drawing conclusions.

\section{RESULT}

This section presents the result of the study. The description is about the result from the two cycles namely cycle 1 and cycle 2 . The following is the detail description.

\section{Cycle 1}

Learning material is speaking skill in the form of descriptive text. Learning activity is conducted for 2 x 45 minutes.

\section{a. Planning}

Teacher prepares Learning Implementation Planning (RPP), pictures to identified adjectives, also pretest and posttest.

b. Act Implementation

1. Teacher conducts a pre test

2. Teacher explains present tense sentences (verbal and nominal)

3. Teacher conducts post test

4. Teacher asks students to make conclusion, base from post test result.

c. Observation

During the activity, students feel excited, enthusiast to mention adjectives base on pictures. There is no one who feel lazy, sleepy, nervous and afraid to express their mind in English, all students lough when one of them makes incorrect answer.

d. Reflection

Observation result in the first cycle (1) shows that in the next meeting needs to be repeated with better presentation. It will be shown in grading result by using picture media in general.

Table 1. Cycle I Learning Performance 


\begin{tabular}{|c|c|c|c|c|}
\hline \multirow[b]{2}{*}{ No } & \multirow{2}{*}{$\mathrm{Name}$} & \multicolumn{3}{|c|}{ Activity } \\
\hline & & Good & Average & Less \\
\hline 1. & DWS & & & $\sqrt{ }$ \\
\hline 2. & BTY & & $\sqrt{ }$ & \\
\hline 3. & DSN & & $\sqrt{ }$ & \\
\hline 4. & FA & $\sqrt{ }$ & & \\
\hline 5. & DHA & $\sqrt{ }$ & & \\
\hline 6. & DTS & & $\sqrt{ }$ & \\
\hline 7. & $\mathrm{RP}$ & $\sqrt{ }$ & & \\
\hline 8. & MA & & & $\sqrt{ }$ \\
\hline 9. & JSL & & $\sqrt{ }$ & \\
\hline 10. & Ardi N. & & $\sqrt{ }$ & \\
\hline 11. & DY & $\sqrt{ }$ & & \\
\hline 12. & MP & $\sqrt{ }$ & & \\
\hline 13. & $\mathrm{AK}$ & $\sqrt{ }$ & & \\
\hline 14. & HT & $\sqrt{ }$ & & \\
\hline 15. & SQ & $\sqrt{ }$ & & \\
\hline 16. & FA & & & $\sqrt{ }$ \\
\hline 17. & $\mathrm{NJ}$ & $\sqrt{ }$ & & \\
\hline 18. & $\mathrm{P}$ & $\sqrt{ }$ & & \\
\hline 19. & $\mathrm{AT}$ & & $\sqrt{ }$ & \\
\hline 20. & ERS & & & $\sqrt{ }$ \\
\hline 21. & RE & & $\sqrt{ }$ & \\
\hline 22. & $\mathrm{M}$ & & $\sqrt{ }$ & \\
\hline 23. & CL & $\sqrt{ }$ & & \\
\hline 24. & $\mathrm{CF}$ & $\sqrt{ }$ & & \\
\hline 25. & AY & & $\sqrt{ }$ & \\
\hline 26. & TT & $\sqrt{ }$ & & \\
\hline 27. & FN & $\sqrt{ }$ & & \\
\hline 28. & $\mathrm{~B}$ & $\sqrt{ }$ & & \\
\hline 29. & $\mathrm{G}$ & & & $\sqrt{ }$ \\
\hline 30. & $\mathrm{~K}$ & & & $\sqrt{ }$ \\
\hline 31. & I & $\sqrt{ }$ & & \\
\hline 32. & DL & $\sqrt{ }$ & & \\
\hline 33. & AS & & $\sqrt{ }$ & \\
\hline 34. & PS & & & $\sqrt{ }$ \\
\hline & Total & 17 & 10 & 7 \\
\hline & Mean & - & - & - \\
\hline & Precentage & $50 \%$ & $29 \%$ & $21 \%$ \\
\hline
\end{tabular}

Based on the data, students' learning performance by using picture media in general shows that average grade from each students is 62,38 , while minimum completeness criteria (KKM) is stated in the grade of 75 . Since the grade that reached is under minimum completeness criteria, it needs to continue in the second cycle (cycle II).

Table 2. Cycle I Learning Activity Observation

\begin{tabular}{|c|c|c|}
\hline No. & $\mathrm{Name}$ & Students' Learning Performance \\
\hline 1. & DWS & 56 \\
\hline 2. & BTY & 60 \\
\hline 3. & $\overline{\mathrm{DSN}}$ & 58 \\
\hline 4. & FA & 61 \\
\hline 5. & DHA & 60 \\
\hline 6. & DTS & 62 \\
\hline 7. & RP & 59 \\
\hline 8. & MA & 63 \\
\hline 9. & JSL & 58 \\
\hline 10. & Ardi N. & 63 \\
\hline 11. & DY & 60 \\
\hline 12. & MP & 61 \\
\hline
\end{tabular}

English Teaching Journal, Vol. 7, No. 1, June 2019: 38 - 45 


\begin{tabular}{|c|c|c|}
\hline 13. & AK & 62 \\
\hline 14. & HT & 65 \\
\hline 15. & SQ & 70 \\
\hline 16. & FA & 59 \\
\hline 17. & $\mathrm{NJ}$ & 60 \\
\hline 18. & $\mathrm{P}$ & 71 \\
\hline 19. & AT & 60 \\
\hline 20. & ERS & 58 \\
\hline 21. & RE & 60 \\
\hline 22. & $\mathrm{M}$ & 60 \\
\hline 23. & $\mathrm{CL}$ & 61 \\
\hline 24. & $\mathrm{CF}$ & 72 \\
\hline 25. & AY & 59 \\
\hline 26. & TT & 60 \\
\hline 27. & $\mathrm{FN}$ & 75 \\
\hline 28. & B & 68 \\
\hline 29. & $\mathrm{G}$ & 59 \\
\hline 30. & $\mathrm{~K}$ & 58 \\
\hline 31. & I & 75 \\
\hline 32. & DL & 72 \\
\hline 33. & AS & 58 \\
\hline 34. & PS & 58 \\
\hline \multirow{2}{*}{\multicolumn{2}{|c|}{$\frac{\text { Tot a l }}{\text { Mean }}$}} & 2121 \\
\hline & & 62,38 \\
\hline
\end{tabular}

From the observation result in cycle I (1) above identifies that $50 \%$ or 17 students have good activity in learning process by the using of favorite picture media. Then 10 students have average criteria (29\%), and 7 students have less criteria (21\%). Therefore it needs to conduct cycle II

\section{Cycle II}

The material which is taught in cycle II is speaking in the form of short descriptive text by speaking indicator in the form of descriptive. Learning activity is in 2 x 45 minutes. There following is the detail explanation:

1. Planning

Make learning planning (RPP) and syllabus

Material performing and evaluation

2. Acting

a. Teacher divides the students into 8 groups, each group's consist of 4 students

b. Each groups is asked to find their favorite picture through media

c. Teacher asks the students to discuss learning through picture to find adjective base on the picture, such as: tall, beautiful, long, etc.

d. Each group presents their favorite picture through LCD, describe the picture in the form of descriptive text (it is a posttest).

3. Observation

From the observation shows that students' enthusiasm is shown when they talking about favorite picture in descriptive sentence. They are very enthusiastic in describing what they know in their favorite picture that stated in descriptive text. It can be seen in cycle II observation result as followed:

Tabel 3. Cycle II Learning Performance

\begin{tabular}{|c|c|c|c|c|}
\hline \multirow[b]{2}{*}{ No. } & \multirow[b]{2}{*}{$\mathrm{Name}$} & \multicolumn{3}{|c|}{ Activity } \\
\hline & & Good & Average & Less \\
\hline 1. & DWS & & $\sqrt{ }$ & \\
\hline 2. & BTY & $\sqrt{ }$ & & \\
\hline 3. & DSN & $\sqrt{ }$ & & \\
\hline 4. & FA & $\sqrt{ }$ & & \\
\hline 5. & DHA & $\sqrt{ }$ & & \\
\hline
\end{tabular}

The implementation of favorite picture media for increasing speaking skill... (Masning Suaidah) 


\begin{tabular}{|c|c|c|c|c|}
\hline 6. & DTS & $\sqrt{ }$ & & \\
\hline 7. & $\mathrm{RP}$ & $\sqrt{ }$ & & \\
\hline 8. & MA & $\sqrt{ }$ & & \\
\hline 9. & JSL & & $\sqrt{ }$ & \\
\hline 10. & Ardi N. & $\sqrt{ }$ & & \\
\hline 11. & DY & $\sqrt{ }$ & & \\
\hline 12. & MP & $\sqrt{ }$ & & \\
\hline 13. & AK & $\sqrt{ }$ & & \\
\hline 14. & HT & $\sqrt{ }$ & & \\
\hline 15. & SQ & $\sqrt{ }$ & & \\
\hline 16. & FA & $\sqrt{ }$ & & \\
\hline 17. & $\mathrm{NJ}$ & $\sqrt{ }$ & & \\
\hline 18. & $\mathrm{P}$ & $\sqrt{ }$ & & \\
\hline 19. & AT & & $\sqrt{ }$ & \\
\hline 20. & ERS & $\sqrt{ }$ & & \\
\hline 21. & $\mathrm{RE}$ & $\sqrt{ }$ & & \\
\hline 22. & $\mathrm{M}$ & $\sqrt{ }$ & & \\
\hline 23. & $\mathrm{CL}$ & $\sqrt{ }$ & & \\
\hline 24. & $\mathrm{CF}$ & $\sqrt{ }$ & & \\
\hline 25. & AY & $\sqrt{ }$ & & \\
\hline 26. & TT & $\sqrt{ }$ & & \\
\hline 27. & $\mathrm{FN}$ & $\sqrt{ }$ & & \\
\hline 28. & B & $\sqrt{ }$ & & \\
\hline 29. & $\mathrm{G}$ & $\sqrt{ }$ & & \\
\hline 30. & $\mathrm{~K}$ & & $\sqrt{ }$ & \\
\hline 31. & $\mathrm{I}$ & $\sqrt{ }$ & & \\
\hline 32. & DL & $\sqrt{ }$ & & \\
\hline 33. & AS & $\sqrt{ }$ & & \\
\hline 34. & PS & $\sqrt{ }$ & & \\
\hline & Tot a l & 30 & 4 & - \\
\hline & Mean & - & - & - \\
\hline & Precentage & $88 \%$ & $12 \%$ & $0 \%$ \\
\hline
\end{tabular}

From above data shows that $88 \%$ or 30 students have good activity in learning process by the using of celebrity picture media and 4 students $(12 \%)$ have average criteria, while $0 \%$ student has less criteria. From the data can be concluded that it does not need to continue in the next cycle because it has completed the observation criteria for $70 \%$.

\section{Reflection}

Based on the observation result in cycle II, it identifies that all students have involved actively and able to answer the questions completely. By the using of favorite picture media, students can speak in English well especially on descriptive text easily. The class atmosphere is more conducive and learning activity is more fun. Moreover, the most important thing is that the students are not afraid to speak in English.

Table 4. Cycle II Learning Activity Observation

\begin{tabular}{|c|c|c|}
\hline No. & Na m e & Students' Learning Performance \\
\hline 1. & DWS & 78 \\
\hline 2. & BTY & 80 \\
\hline 3. & DSN & 80 \\
\hline 4. & FA & 82 \\
\hline 5. & DHA & 80 \\
\hline 6. & DTS & 80 \\
\hline 7. & RP & 82 \\
\hline 8. & MA & 84 \\
\hline 9. & JSL & 78 \\
\hline 10. & Ardi N. & 82 \\
\hline 11. & DY & 82 \\
\hline 12. & MP & 80 \\
\hline
\end{tabular}




\begin{tabular}{|c|c|c|}
\hline 13. & $\mathrm{AK}$ & 82 \\
\hline 14. & HT & 82 \\
\hline 15. & SQ & 80 \\
\hline 16. & FA & 80 \\
\hline 17. & $\mathrm{NJ}$ & 80 \\
\hline 18. & $\mathrm{P}$ & 82 \\
\hline 19. & AT & 80 \\
\hline 20. & ERS & 80 \\
\hline 21. & RE & 80 \\
\hline 22. & $\mathrm{M}$ & 80 \\
\hline 23. & CL & 82 \\
\hline 24. & $\mathrm{CF}$ & 80 \\
\hline 25. & AY & 80 \\
\hline 26. & TT & 82 \\
\hline 27. & FN & 80 \\
\hline 28. & $\mathrm{~B}$ & 82 \\
\hline 29. & $\mathrm{G}$ & 80 \\
\hline 30. & $\mathrm{~K}$ & 80 \\
\hline 31. & I & 80 \\
\hline 32. & DL & 84 \\
\hline 33. & AS & 80 \\
\hline & PS & 82 \\
\hline & Total & 2746 \\
\hline
\end{tabular}

From the data identifies that by the using of celebrity picture media, students' average grade is 80 , while minimum completeness criteria is 75 . Since the grade is above minimum completeness criteria, it does not need to continue in cycle III because it has completed grading standard in favorite picture media learning material.

\section{DISCUSSION}

The implementation of favorite picture media to increase speaking skill in the form of descriptive text that conducted in 10th MIPA 6 grade students of SMAN I Kawedanan Magetan, first semester of academic year 2017/2018 is divided into two cycles, cycle I and II.

On Cycle I identifies that $50 \%$ or 17 students have good activity in learning process by using celebrity picture media, and 10 students have average criteria (29\%). While $21 \%$ (7 students) have less activity.

The result of learning performance by using favorite picture media in average is 62,38 , which reach out the English minimum completeness criteria (KKM) is 75. It is because the students have not gotten the usage of the implementation of favorite picture media, so only $50 \%$ of students have good learning activity. According to Djamarah (2008) learning activity is all of students' activity in learning process, begins from physical until psychic activity.

Physical activities are in the form of basic skills while psychic activities are in the form of integrated skills. Activities in the learning process are a series of activities which include the activity of students in attending lessons, thinking, reading, and all activities carried out that can support learning outcomes (Sardiman, 2011). Thus it can be concluded that the activeness of students in the class will affect their learning achievement. If learning activities are good, then their learning achievement is good. Because the average value is still less than the KKM, which is 75 , the study is continued in cycle II.

The second cycle, from 34 students as many as 30 students or $88 \%$ students had good activities in learning process by using favorite picture media. 4 students have medium criteria which ranges from $12 \%$ while $0 \%$ have less activity. So that from the data it is concluded that there is no need to carry out the next cycle activities because in the second cycle it has fulfilled the observation criteria of $88 \%$ and student learning outcomes using favorite picture media on an average score of 80, where the KKM in English subjects is determined into 75. Because the average value is above the KKM, the next cycle is not necessary. This is due to having already has a standard of assessment in subject by using the favorite picture media, which further, increase learning interest improve learning performance.

Learning media is "Everything that can be used as a tool to connect information on messages in the teaching and learning process, so it can stimulate thoughts, feelings, attention, and interest in students and can deepen and broaden students' understanding" (Isbani, 1986: 10). 
Basically, it is not the media of learning itself that determines learning outcomes. It turns out that the success of using learning media in the learning process to improve learning outcomes depends on (1) the content of the message, (2) how to explain the message, and (3) the characteristics of the recipient of the message. Thus in choosing and using media, these three factors need to be considered. If the three factors are able to be delivered in learning media, of course, they will give maximum results (Sadirman, 2007).

Speaking skills in English is a skill for someone to convey his/ her desires and thoughts to anyone through oral, however, speaking skills are difficult to develop if not trained or lack of learning. One of the difficulties in learning speaking is the silence of students in the classroom. Therefore teacher stimulation is needed so students can improve their speaking skills.

In this study the use of favorite picture media is proved to be able to improve students' speaking skills in the form of descriptive text that shown by the increasing of students' achievement. This is in line with the opinion of Rowntree (in Ahmad Rohani, 2007) says that learning media has significant functions in the teaching and learning process, namely: a) arousing learning motivation. b) Repeat what has been learned. c) Provide learning stimulation. d) Activate student responses. e) Give immediate feedback. f) Promote matching exercises. Based on the description it is very clear that the use of learning media can improve student learning achievement.

\section{CONCLUSION}

The research result shows that favorite picture media can help the students to increase their ability in English speaking skill. Moreover, it can be concluded that by the using of favorite picture media, is able to increase speaking learning interest in the form of descriptive text. Learning process by the using of favorite picture media is simplify students in speaking in descriptive text. Students' learning interest and activity are increased. It is proven by daily test average grade that the students reach 80 grade. It means above the minimum completeness criteria. The goal speaking material in the form of descriptive text is reached out as teacher's expectation.

Thus, this study it is expected that English language teachers can take advantage of this research. Also able to apply in English language learning activities. By using favorite picture media the quality of learning increases. This is intended to facilitate students in understanding and improving learning achievement. The principal is expected to be able to support the procurement of learning media. The future researcher is suggested to apply this media to help the students in increasing their speaking skill. It can be done in another skill of English such as reading and writing skill.

\section{REFERENCES}

Abidin, Zaenal. 1981. Pemilihan dan Penggunaan Media Dalam Proses Belajar Mengajar. Jakarta.

Ahmad Rohani dan Abu Ahmadi. 2007. Pengelolaan Pengajaran. Jakarta: Rineka.

A.M. Sardiman. 2011. Interaksi dan Motivasi Belajar Mengajar. Jakarta: Rajawali Press.

Arikunto, Suharsini. 2006. Penelitian Tindakan Kelas. Jakarta : Bumi Aksara

Budiningsih, C. Asri. 2005. Belajar dan Pembelajaran. Jakarta : Rineka Cipta.

Djamarah, Syaiful Bahri. 2008. Psikologi Belajar. Jakarta: Rineka Cipta. Hendrayana,

Hastuti, Sri, PH. 1982. Tulis Menulis.

Oemar, H. Malik. 1985. Media Pendidikan. Bandung.

Milles, Matthew B., Huberman, A. Michael. 2012. Analisis Data Kualitatif. Jakarta: Universitas Indonesia Press

Mulyasa. 2013. Kurikulum Berbasis Kompetensi: Konsep, Karakteristik, dan Implementasi. Bandung: PT Remaja Rosdakarya.

English Teaching Journal, Vol. 7, No. 1, June 2019: $38-45$ 
Nunan, David, 2011. Language Teaching Methodology, Great Britain: Prentice Hall International

Sukardi. 2015. Metodologi Penelitian Pendidikan: Kompetensi dan Praktiknya. Jakarta: PT Bumi Aksara.

Tarigan, Jago. 1999. Pengembangan Keterampilan Berbicara. Jakarta.

Webster, 1994. The New Grolier Webster Dictionary of English Language. America 